\title{
Attitude of B.Ed. Student-Teachers towards Practicum
}

\author{
Ankur Mahato ${ }^{1}$, Dr. Santosh Kumar Behera ${ }^{2 *}$ \\ ${ }^{1}$ B.Ed. Student-Teacher, AMGTT College, Anandanagar, Baglata, Purulia, West Bengal, INDIA \\ ${ }^{2}$ Assistant Professor, Department of Education, Sidho-Kanho-Birsha University, Purulia \\ West Bengal, INDIA \\ santoshbehera.jkc@gmail.com
}

Abstract: In the present study the investigators made an attempt to know the B.Ed. student-teachers attitude towards Practicum in Purulia district of West Bengal, India. 250 B.Ed. Student-Teachers of one Govt. Sponsored (47) and four Self Financing / Private (203) B.Ed. Colleges (both Urban and Rural areas) affiliated to SidhoKanho-Birsha University in Purulia District of West Bengal were taken as representative sample of the whole population. For selecting the student- teachers stratified random sampling was adopted. An attitude scale was used for collecting the data. The means of both groups were tested for significance of difference by using t-test and F-test. The study revealed that the attitude of B.Ed. Student-Teachers in Purulia District of West Bengal is neither more favorable nor unfavorable towards Practicum i.e., satisfactory or average in attitude. The study also revealed that attitude of Male and Female, Rural and Urban, as well as Govt. Sponsored and Private B.Ed College B.Ed. student-teachers towards Practicum differs significantly. On the other hand, attitude of Preservice and In-service, $2^{\text {nd }}$ Semester and $4^{\text {th }}$ Semester, Less than $5 y$ rs and Above 5 yrs teaching experience, Arts and Science, less than 5 years, above 5 years and Fresher teaching experience as well as General, SC, ST and OBC B.Ed. student-teachers towards Practicum did not differ significantly.

Keywords: Attitude, Practicum, B.Ed., Student-Teachers, NCTE INTRODUCTION

Practicum is a course of study designed especially for the preparation of teachers' clinicians that involves the supervised practical application of previously studied theory. Practicum is considered an essential strategy for preparing would-be teachers to be competent teachers. It works as a pre-service teacher education program. This might be because a student teacher has to learn about teaching and about how to teach. Such practical education was given the name "teacher education" that aims to help student teachers in their development from student teachers to qualified teachers and to encourage change in their earlier views of teaching. Tuli (2009) maintained that practicum requires the would- be- teachers to spend a significant portion of their preservice program in schools, observing teachers, classrooms, the school environment and practicing teaching specific subject related to their field of study with the intention to integrate campus experience with school based practicum experience in a meaningful way. The practicum course provides an opportunity for the student teachers to apply the most important concepts, principles and educational theories in real teaching situations at school. Such real applications are hoped to provide the student teachers with good opportunities to acquire the required educational competencies they need to be competent. A number of terms such as the teaching practice, practicum, student teaching, field studies, infield experience, school based experience or internship are used to refer to the activity of practice teaching (Haigh \& Tuck, 1999). Practicum is a course or program in which the students or trainees are ported to schools normally lower than their institution of learning, to teach the student subject areas of their specialization for a specific period. During the period student teachers as they are called, assume the position of normal subject teachers and the same time engage in all lawful assignments given by the cooperative school authorities (Mohan \& Ghosh, 2011). Thus, this course consists of 
three main stages: 1. Observation Stage: At this stage, the student- teacher is expected to spend one week (20 hours) at the cooperative school where he is given the chance and the required support to observe different inclass and outside practices and activities such as: observing disciplinary procedures, school management, staff relations and meetings, ordering and ranking students, attending educational meetings. The aim of this stage is to become acquainted with school life in general. Wallace (1991) maintained that observation does not simply mean watching classes. The trainee should have a practical experience in which he/she responds to a number of tasks relating to various important aspects of school life. 2. Participation Stage: Here the student teacher spends two weeks (40 hours) in practicing educational tasks and activities inside and outside classroom. For example, he/she is advised to participate at school committees and their activities, write and conduct lesson planning, prepare worksheets, take class attendance and the like. Such participation can be performed independently or with the help of the cooperative teacher. At the beginning of this stage, the university practicum supervisor visits the student to give guidelines and orientation that can help the student improve the educational practices and to cooperate in school activities. 3. Actual Practice: This is the most important stage as it forms the real practices of teaching because at this final stage, student teachers are to be familiar with the multiple tasks of a classroom teacher. Wallace (1991) named this stage "the teaching practice) and defined it as the opportunity given to the trainee to develop and improve her/his professional practice in the context of a real classroom, usually under some form of guidance or supervision. This teaching practice forms one part of a wider term called "school experience" which refers to the total experience of working in a school when the trainees have been allocated to a particular school as part of their professional development. At this stage which lasts for three weeks (60 hours), the student teacher is given the opportunity to practice teaching in real teaching situations where he/she plans, writes behavioural objectives, teaches, uses different methods of teaching, uses different types of audiovisual aids, evaluates, and gives feedback. During this stage, the faculty member visits the student teacher for the second time in order to evaluate and assess his/her performance in class. This visit is given 40 $\%$ of the total grade.

As per NCTE New Regulation, 2014 the B.Ed. curriculum designed to integrate the study of subject knowledge, human development, pedagogical knowledge and communication skills. The programme comprised three broad curricular areas: Perspectives in Education, Curriculum and pedagogic Studies and Engagement with the Field. The B.Ed. programme shall provide for sustained engagement with the Self, the Child, Community and School, at different levels and through establishing close connections between different curricular areas. This curricular area would serve as an important like between the above two broad curricular areas through its three components:

(i) Tasks and assignments that run through all the courses.

(ii) School Internship.

(iii) Course on Enhancing Professional Capacities.

The curricular areas of 'Perspectives in Education' and 'Curriculum and pedagogic Studies' shall offer field engagement through different task and project with the community, the school and the child in school and out-of-school. These tasks and projects would hold in substantiating perspectives the theoretical frameworks study in a teacher education classroom with field-based experience. The tasks and projects may include collaborative partnership with the school for developing CCE practices, establishing study circles/forums for professional development of in-service school teachers, or dialoguing with the school management committee, etc. Community-based encouragement may also include oral history projects with a community of artisans as a part of 'Contemporary India and Education' or 'Pedagogy of Social Science/ History. Likewise, the pedagogy course on Science may include environment projects to address concerns of a particular village / city or a community. 
Attitude of B.Ed. Student-Teachers towards Practicum

Glimpse of Practicum as per Two-Year B. Ed. Programme, NCTE New Regulation 2014

\begin{tabular}{|c|c|c|c|}
\hline Semester & Theory & Engagement with the field & Total \\
\hline $1^{\text {st }}$ & 325 & 175 & 500 \\
\hline $2^{\text {nd }}$ & 325 & 175 & 500 \\
\hline $3^{\text {rd }}$ & 50 & 450 & 500 \\
\hline $4^{\text {th }}$ & 300 & 200 & 500 \\
\hline Total & $\mathbf{1 0 0 0}$ & $\mathbf{1 0 0 0}$ & $\mathbf{2 0 0 0}$ \\
\hline
\end{tabular}

So it is said that Practicum is the very importance part of B.Ed. curriculum. Practicum helps to all-round development among the Student-Teachers.

From the above discussion, it is clear that Practicum is the very essential part of B.Ed. programme for the development of teaching skills as well as professional skills among the student-teachers. Without practicum, B.Ed. Programme is worthless. So, proper understanding of practicum in Two-year B.Ed. programme in the student-teachers is inevitable. As per NCTE two-year B.Ed. Programme practicum as equal significance as theory. It is found that there are different reasonable opinions in this regards. But we cannot come to a conclusion about all the Student- Teachers' attitude towards Practicum in Two-Year B.Ed. Programme from several comment or discussions with handful Student-Teachers only. Many questions are arising in the researchers mind about the Student-Teachers attitude towards Practicum at Secondary training level. Still now it is very important and sensitive issue. It is an urgent need for developing certain strategies which can improve their knowledge, attitude and skills towards practicum in Two-Year B.Ed. Programme. Therefore, in order to know the attitude of B.Ed. Student-Teachers towards Practicum, the investigators have decided to take up a systematic and objective attitudinal study of B.Ed. Student-Teachers towards Practicum. The investigators intend to restrict their research work to Purulia District of West Bengal.

\section{NEED AND SignificAnce OF THE STUdy}

Teacher education is an integral part of education. It is the spotlight of the $21^{\text {st }}$ century. Thus the quality of education depends on the quality of education of teachers. The success of education depends on quality of teacher which creates excellence in all walks of life. The qualitative aspect of education depends entirely on the character and personality of the teachers. The quality of education depends upon the quality of teachers. Thus the role of the teachers is very important in making the nation. In order to develop the quality in various dimensions of teacher, teacher training is very much necessary. Particularly, secondary level teachers training (In service and Pre service) play a vital role in India. The bachelor of Education (B.Ed.) programme prepares quality teachers who in turn improve the quality of school education and also enhance the learning level of children. It means quality of teacher depends on B.Ed. programme. In this direction; many efforts were made by implementing the various recommendations of policy documents as suggested by various commissions and committees in India. The significance of this study emerges from the importance of practicum experience itself, its role in teacher preparation programs which aims to develop the educational competencies of studentteachers, and its ability to diagnose the challenges faced by student-teachers during practicum. The study would be helpful for the improvement of B.Ed. Practicum among the student-teachers of Purulia district. Different B.Ed. colleges of Purulia would get the idea of their effective understanding in practicum. Administration would be able to enhance the similarities of practicum among its different colleges. The attitude of B.Ed. student-teachers towards practicum is important because certain types of attitudes may disrupt the teaching learning process of practicum. Practicum helps to make practical knowledge among the Student-Teachers. It helps to develop their creative thinking among the Student-Teachers and develop their co-operative attitude. Practicum helps to apply various theoretical aspects in practical area. Practicum associates with real life among the StudentTeachers. The identification of attitudes provides a fertile ground in generating intervention programs towards 
Attitude of B.Ed. Student-Teachers towards Practicum

the promotion of the desirable ones. Thus, the study of the attitude of B.Ed. Student-Teachers in Purulia district helps uncover deficiencies which render the implementation of practicum in different B.Ed. Colleges.

\section{Statement of The Problem}

The problem for the present study may be specifically stated as below:

\section{"Attitude of B.Ed. Student-Teachers towards Practicum"}

\section{LITERATURE REVIEW}

Ferrier-Kerr, J. L. (2009) has conducted a study on "Collaborative strategies for developing effective professional relationships in the practicum". The objectives of the study were to identify principles which appeared to be important to the development of the professional relationship between associate teachers and student teachers during the final block practicum, and secondly to identify specific strategies associate teachers employed to support and enhance the professional development of their student teachers. The findings were that the main collaborative strategies that the participants employed were team planning, teaching and modeling by the associate teacher, conversation, the use of reflective journals and the associate teacher acting as a critical friend. The study showed that when the associate teacher took on the role of a critical friend the student teacher was more able to develop greater understanding of effective teaching and learning. Tuli, Fekede. (2009) has conducted a study on "Understanding Undergraduate Students Practicum Experience: A Qualitative Case Study of Jimma University". The objective of the study was examined the pre-service teachers' perspectives of practicum experience as a tool of learning to teach. The findings was that the participants perceived practicum as an important tool of learning to teach because it promoted the development of teaching experience and prepared them for the real world of work. Arroyo, A.R. (2011) has conducted a study on "Practicum performance in Singapore and the Philippines of hospitality students in a state university". The objectives of the study were: 1) to describe the level of implementation of the 0JT program along orientation and monitoring; 2 ) to determine the level of job performance of the on and the off- campus practicumers as rated by their 0JT supervisors along knowledge, skills, and attitudes; 3 ) To determine any difference in the levels of job performance between Singapore and the Philippines practicumers in terms of knowledge, skills, and attitudes; 4) To establish the relationship between the level of implementation of the OJT programs and the level of job performance of the practicumers. The findings were the OJT programs have been implemented effectively, enabling the practicumers sent to Singapore and there assigned in the Philippines to perform well in their jobs as evidenced by the high ratings they obtained in the job performance evaluation by OJT supervisors. The level of implementation of the OJT programs significantly influences the level of job performance of the practicumers. The higher the implementation of the OJT program is, the better the level of job performance of the practicumers is also. Being so, the school and its partner companies should further intensify the 0JT programs in place to fully prepare the practicumers for their OJT and employment afterwards. To make the OJT program more effective, the school should appropriately address the identified concerns of the practicumers. The school should consider sending the practicum adviser to Singapore for a 2-week visit at least once in every six months to effectively monitor the practicumers. Jusoh, Z. (2011) has conducted a study on "Teaching practicum: Student teachers' perspectives". The objective of the study was to examine the problems that faced student-teachers in PTEP at the University of Sultan Zainal Abidin in Malaysia. In-depth interviews were conducted with two student-teachers who completed their practicum. The finding was that student-teachers have faced a variety of challenges, some were personal challenges related to the students themselves, while other challenges were associated with teaching. Starkey, L. and Rawlins, P. (2012) have conducted a study on 'Student teacher learning during practicum experience'. This article explores the focus of student teacher learning during practicum experience in two initial teacher education programmes. Data was gathered through case studies and a cohort questionnaire. Three professional 
learning themes were identified: managing the learning environment, pedagogy, and being a teacher. Initially the student teachers learnt about the context in which they would teach. During practicum the professional learning reported was focused on strategies to manage the learning environment, the process of teaching and what it is like to be a teacher. Findings can inform the focus of learning expectations for students on particular experience within initial teacher education programmes. Dweikat, K.A. (2013) has conducted a study on "Attitudes of TEFL student teachers at QOU towards the implementation of practicum". The objective of the study was to investigate the attitudes of TEFL student teacher towards the implementation of the practicum course at Al- Quds Open University (QOU) in addition to exploring the most stressful obstacles faced by student teachers while trying the practicum experience. The finding of the study was that the attitudes of TEFL student teachers towards the implementation of the practicum course at QOU were positive on all domains except the fourth one. Belete, A. (2013) has conducted a study on "the attitude of school teachers' /mentors/ towards practicum course" in debremarkos town primary school. The objectives of the study were: to investigate the attitudes of partner school teachers about practicum.2) to identify factors which affect the attitudes of Partner School Teachers / Mentors towards Practicum. 3) To recommend means for the development of interest and creating thick relationship between Training College and Partner Schools. The findings of the study were: 1) Mentors of practicum students didn't have deep knowledge on the course and its mission. 2) The additional roles and responsibilities of them due to practicum course never influenced negatively in their work. 3) Direction they took that the absence of incentives didn't affect their attitude to the negative. 4) Factors related to teaching learning process of practicum and their attitudes toward it are directly correlated. Beatrice, M.N (2014) has conducted a study on "Cognition of the role of cooperating teachers during the practicum in Kenya: Teachers of English perspective". The objectives of the study were: 1) to establish teacher's knowledge of the rationale of teaching practice in Kenya. 2) To find out teachers cognition of the role of cooperating teachers during the practicum. The findings of the study were: 1) It is important to enable teachers complete their Post Graduate Diploma in Education (PGDE) or Bachelor of Education Degree (BED) programmes. 2) Enable student teachers to put teacher education theories into practice. 3) To practice how to teach.

\section{DELimitations OF THE STUDY}

The delimitations of the present study are as follows:

\section{(A) Geographical Area}

The investigation was delimited to only Purulia district of West Bengal.

\section{(B) Level of Education}

(i) The study was restricted to the student-teachers in B.Ed. colleges of the said district. (ii) The B.Ed. studentteachers in regular mode (Academic Session: 2015-17 \& 2016-2018) of Govt. Sponsored and Private/Selffinancing B.Ed. training colleges in Purulia district were considered as the subjects of the present study.

\section{(C) Type of Study}

This study was conducted only at surface level. It was not an 'in-depth' study. Attempt to know the subject's attitude by administering an attitude scale constructed by the researchers. No inter-state comparison was done. Only intra- district comparison between the male and female-Student-Teachers, between $2^{\text {nd }}$ and $4^{\text {th }}$ Semester Student-Teachers, among the General, SC, ST and OBC student-teachers, among the Less and Above than 5years and Fresher Student-Teachers, Student-Teachers in Govt. Sponsored and Private Colleges, rural and urban student-teachers, Pre-service and In-service Student-Teachers, between Arts and Science Student-Teachers, Student-Teachers in Govt. Sponsored and Private colleges, between less and above 5 years experienced studentteachers were done. 


\section{OBJECTIVES OF THE STUDY}

1. To ascertain the attitude of B.Ed. Student- Teachers towards in Purulia District of West Bengal.

2. To find out the difference between Male and Female B.Ed. Student- Teachers in respect of their attitude towards Practicum.

3. To find out the difference between Rural and Urban B.Ed. College Student- Teachers in respect of their attitude towards Practicum.

4. To find out the difference between Pre-service and In-service B.Ed. Student- Teachers in respect of their attitude towards Practicum.

5. To find out the difference between Govt. Sponsored and Private B.Ed. College Student- Teachers in respect of their attitude towards Practicum.

6. To find out the difference between $2^{\text {nd }}$ and $4^{\text {th }}$ Semester B.Ed. Student- Teachers in respect of their attitude towards Practicum.

7. To find out the difference between the teaching experience of less and above than 5years a B.Ed. StudentTeachers in respect of their attitude towards Practicum.

8. To find out the difference between the Arts and Science B.Ed. College Student- Teachers in respect of their attitude towards Practicum.

9. To find out the difference among the teaching experience of less and above than 5years and Fresher B.Ed. Student- Teachers in respect of their attitude towards Practicum.

10. To find out the difference among the General, SC, ST and OBC B.Ed. Student- Teachers in respect of their attitude towards Practicum.

\section{HyPOTHESES OF THE STUDY}

The hypotheses were formulated in null form:

$\mathbf{H}_{\mathbf{0 1}}$ : There will have more unfavourable attitude of B.Ed. Student-Teachers towards Practicum.

$\mathbf{H}_{\mathbf{0 2}}$ : There is no significant difference between Male and Female B.Ed. Student-Teachers in respect of their attitude towards Practicum.

$\mathbf{H}_{\mathbf{0 3}}$ : There is no significant difference between Rural and Urban B.Ed. College Student-Teachers in respect of their attitude towards Practicum.

$\mathbf{H}_{\mathbf{0 4}}$ : There is no significant difference between Pre-service and In-service B.Ed. Student-Teachers in respect of their attitude towards Practicum.

$\mathbf{H}_{\mathbf{0 5}}$ : There is no significant difference between Govt. Sponsored and Private B.Ed. College Student-Teachers in respect of their attitude towards Practicum.

$\mathbf{H}_{\mathbf{0 6}}$ : There is no significant difference between $2^{\text {nd }}$ and $4^{\text {th }}$ semester B.Ed. Student-Teachers in respect of their attitude towards Practicum

$\mathbf{H}_{07}$ : There is no significant difference between the teaching experience of less and above than 5 years B.Ed. Student -Teachers in respect of their attitude towards Practicum.

$\mathbf{H}_{\mathbf{0}}$ : There is no significant difference between the Arts and Science B.Ed. College Student -Teachers in respect of their attitude towards Practicum. 
$\mathbf{H}_{09}$ : There is no significant difference among the teaching experiences of less and above than 5 years and Fresher B.Ed. Student-Teachers in respect of their attitude towards Practicum.

$\mathbf{H}_{\mathbf{0 1 0}}$ : There is no significant difference among the General, SC, ST and OBC B.Ed. Student-Teachers in respect of their attitude towards Practicum.

\section{METHOD OF THE STUDY}

The present study is based on survey method, particularly, the normative survey research method.

\section{Population of the Study}

The B.Ed. Student-Teachers in Purulia District of West Bengal comprised the population of this study.

\section{The Sample and Sampling Procedure}

250 B.Ed. Student-Teachers of one Govt. Sponsored (47) and four Self Financing / Private (203) B.Ed. Colleges (both Urban and Rural areas) affiliated to Sidho-Kanho-Birsha University in Purulia District of West Bengal were taken as representative sample of the whole population. Purposive sampling technique was adopted for selecting the B.Ed. Colleges. For selecting the student-teachers stratified random sampling was adopted. The detailed category wise breakup of the samples is as follows:

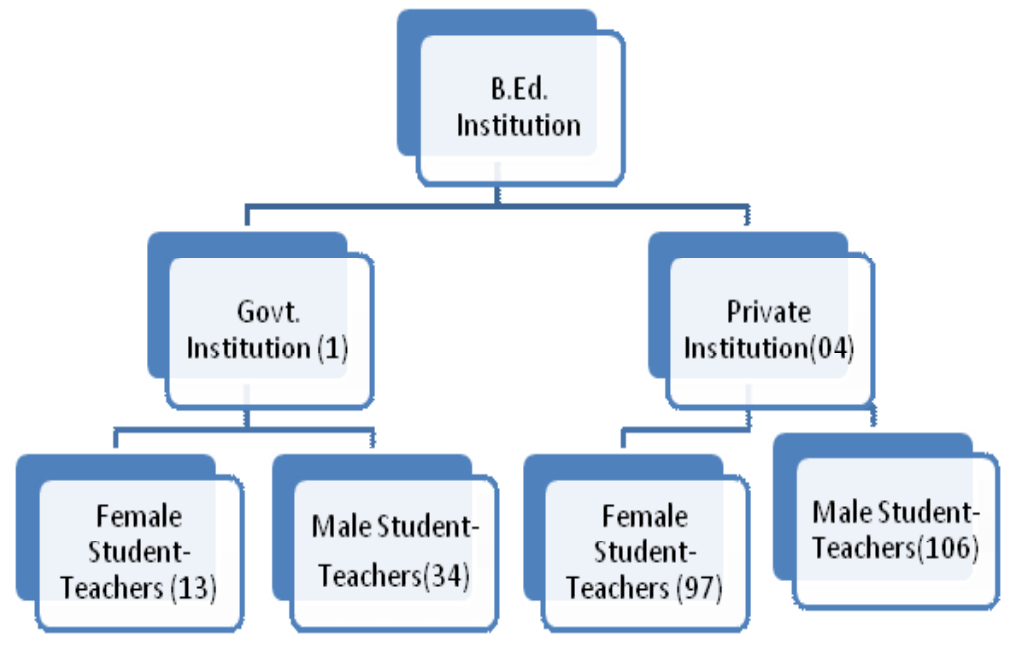

\section{The Tool Used}

An attitude scale (Likert Type) was used for knowing the attitude of the B.Ed. student-teachers towards Practicum.

Table1. Scoring Procedure

\begin{tabular}{|c|c|c|c|c|c|}
\hline ITEMS & $\begin{array}{c}\text { STRONGLY } \\
\text { AGREE (A) }\end{array}$ & AGREE (B) & NEUTRAL (C) & $\begin{array}{c}\text { DISAGREE } \\
\text { (D) }\end{array}$ & $\begin{array}{c}\text { STRONGLY } \\
\text { DISAGEREE (E) }\end{array}$ \\
\hline Favourable & 5 & 4 & 3 & 2 & 1 \\
\hline Unfavourable & 1 & 2 & 3 & 4 & 5 \\
\hline
\end{tabular}

\section{Variables of the Study}

Variable is an attribute which is regarded as reflecting or expressing some concepts or constructs. In the present study there are two types of variables - Independent variables and Dependent variable. These variables are diagrammatically given below: 


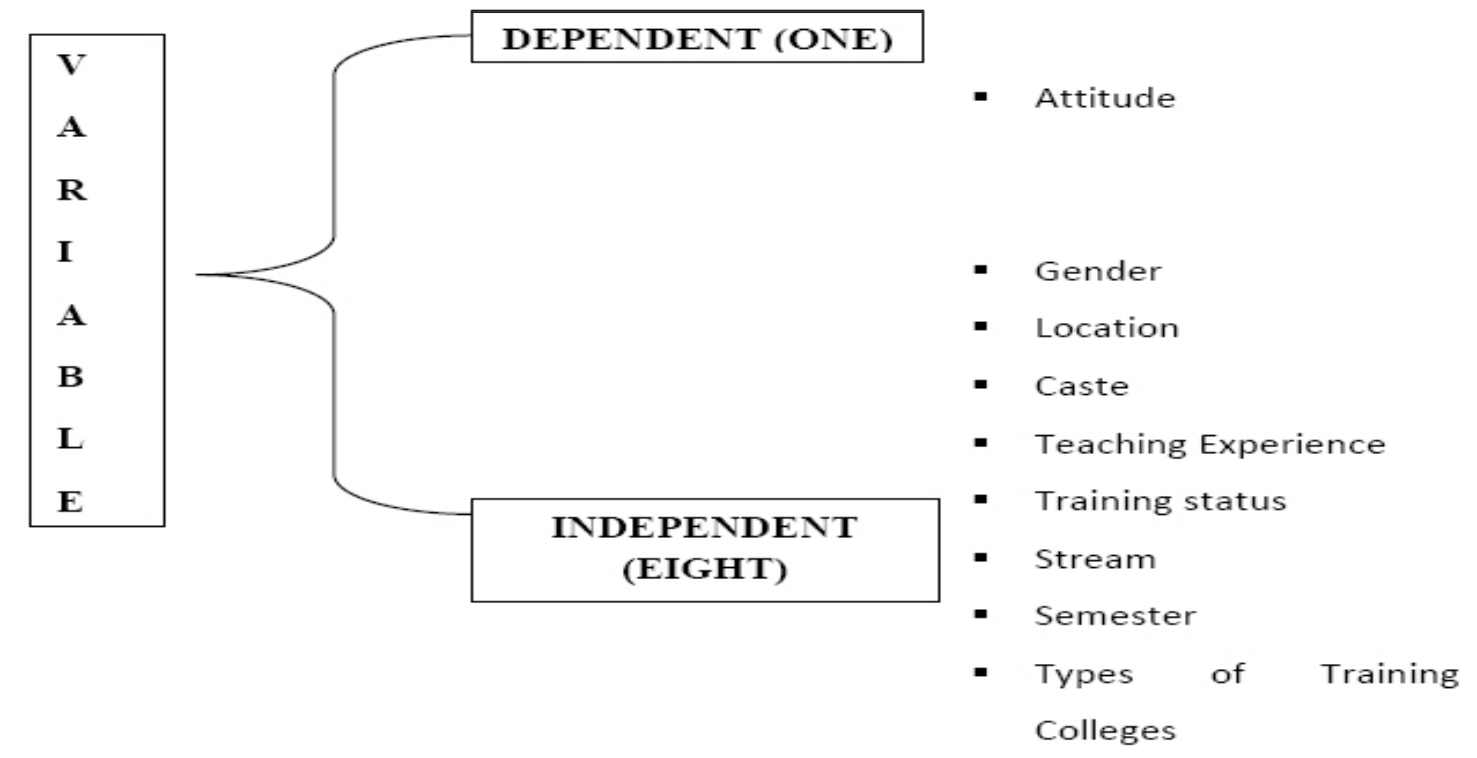

\section{Statistical Techniques}

Percentage, Mean, SD, F \& t- tests were used to analyse the collected dada. ANOVAs and t tests were used to verify the hypotheses.

\section{RESULTS \& DiscusSiONS}

Testing of $\mathbf{H}_{01}$

The B.Ed. Student-Teachers will have more unfavourable attitude towards Practicum in Purulia district of West Bengal.

\section{Category N Mean S.D \\ B.Ed. Student-Teachers $\quad 250 \quad 136.82 \quad 15.16$}

Through the help of cut-off point the investigator verified the $\mathrm{H}_{1}$. Here Cut-off Point is $\mathrm{M} \pm 1 \sigma$. It means, $\mathrm{Mean}=136.82, \mathrm{~N}=250$ and $\sigma=15.16$. Hence $\mathrm{M}+1 \sigma$ is $136.82+1 \mathrm{x} 15.16=151.98$. And $\mathrm{M}-1 \sigma=136.82-1 \mathrm{x}$ $15.16=121.66$. Most of B.Ed. Student-Teacher (167 in number) i.e., $66.80 \%$ of B.Ed. Student-Teachers were lies between 121.66 to 151.98 scores. Hence, it can be said that the attitude of B.Ed. Student-Teachers in Purulia District of West Bengal is neither more favorable nor unfavorable towards B.Ed. Practicum i.e., satisfactory or average in attitude towards B.Ed. Practicum.

Table2. The attitude of B.Ed. Student-Teachers in Purulia District of West Bengal towards B.Ed. Practicum.

\begin{tabular}{|c|c|c|c|}
\hline Scores & Frequency & Percentage & Levels of Attitude \\
\hline Above 151.98 & 43 & $17.20 \%$ & Favorable \\
\hline Between121.66-151.98 & 167 & $66.80 \%$ & Moderate / Average \\
\hline Below 121.66 & 40 & $16 \%$ & Unfavorable \\
\hline TOTAL & $\mathbf{2 5 0}$ & $\mathbf{1 0 0}$ & \\
\hline
\end{tabular}

From the table 2 it is found that the attitude of B.Ed. Student-Teachers towards Practicum is moderate level (Through the analysis of cut off point that $\mathrm{M} \pm 1 \sigma$ on the other hand). 
Attitude of B.Ed. Student-Teachers towards Practicum

Table3. Showing significant of difference between Variables

\begin{tabular}{|c|c|c|c|c|c|c|c|c|}
\hline Group & $\mathbf{N}$ & Mean & SD & $\begin{array}{c}\text { Mean } \\
\text { Difference }\end{array}$ & $S_{E D}$ & df & $\mathbf{t}$ & $\begin{array}{c}\text { Level of } \\
\text { Significance }\end{array}$ \\
\hline $\begin{array}{l}\text { Male B.Ed. Student- } \\
\text { Teachers }\end{array}$ & 140 & 138.52 & 15.47 & \multirow{2}{*}{3.87} & \multirow{2}{*}{1.92} & \multirow{2}{*}{248} & \multirow{2}{*}{2.01} & \multirow{2}{*}{$\begin{array}{c}\text { Significant at } 0.05 \\
\text { level }\end{array}$} \\
\hline $\begin{array}{l}\text { Female B.Ed. Student- } \\
\text { Teachers }\end{array}$ & 110 & 134.65 & 14.62 & & & & & \\
\hline $\begin{array}{l}\text { Rural B.Ed. College } \\
\text { Student-Teachers }\end{array}$ & 148 & 139.89 & 13.86 & \multirow{2}{*}{7.53} & \multirow{2}{*}{1.90} & \multirow{2}{*}{248} & \multirow{2}{*}{3.96} & \multirow{2}{*}{$\begin{array}{l}\text { Significant at } 0.01 \\
\quad \& 0.05 \text { level. }\end{array}$} \\
\hline $\begin{array}{l}\text { Urban B.Ed. College } \\
\text { Student-Teachers }\end{array}$ & 102 & 132.36 & 15.99 & & & & & \\
\hline $\begin{array}{l}\text { Pre-service B.Ed. Student- } \\
\text { Teachers }\end{array}$ & 233 & 136.73 & 15.08 & \multirow{2}{*}{1.39} & \multirow{2}{*}{3.82} & \multirow{2}{*}{248} & \multirow{2}{*}{0.36} & \multirow{2}{*}{$\begin{array}{l}\text { Not Significant at } \\
0.01 \& 0.05 \text { level }\end{array}$} \\
\hline $\begin{array}{l}\text { In-service B.Ed. Student- } \\
\text { Teachers }\end{array}$ & 17 & 138.12 & 17.10 & & & & & \\
\hline $\begin{array}{l}\text { Government Sponsored } \\
\text { B.Ed. College Student- } \\
\text { Teachers }\end{array}$ & 47 & 129.04 & 15.96 & \multirow[b]{2}{*}{9.58} & \multirow[b]{2}{*}{2.39} & \multirow[b]{2}{*}{248} & \multirow[b]{2}{*}{4.01} & \multirow{2}{*}{$\begin{array}{l}\text { Significant at } 0.01 \\
\quad \& 0.05 \text { level }\end{array}$} \\
\hline $\begin{array}{l}\text { Private B.Ed. College } \\
\text { Student- Teachers }\end{array}$ & 203 & 138.62 & 14.46 & & & & & \\
\hline $\begin{array}{l}2^{\text {nd }} \text { Semester B.Ed. } \\
\text { Student-Teachers }\end{array}$ & 120 & 136.02 & 14.62 & \multirow{2}{*}{1.54} & \multirow{2}{*}{1.92} & \multirow{2}{*}{248} & \multirow{2}{*}{0.80} & \multirow{2}{*}{$\begin{array}{l}\text { Not Significant at } \\
0.01 \& 0.05 \text { level }\end{array}$} \\
\hline $\begin{array}{l}4^{\text {th }} \text { Semester B.Ed. } \\
\text { Student-Teachers }\end{array}$ & 130 & 137.56 & 15.71 & & & & & \\
\hline $\begin{array}{l}\text { Less than } 5 \text { years Experi. } \\
\text { B.Ed. Student-Teachers }\end{array}$ & 12 & 137.67 & 14.98 & \multirow[b]{2}{*}{1.53} & \multirow[b]{2}{*}{9.39} & \multirow[b]{2}{*}{15} & \multirow[b]{2}{*}{0.16} & \multirow{2}{*}{$\begin{array}{l}\text { Not ignificant at } \\
0.01 \& 0.05 \text { level }\end{array}$} \\
\hline $\begin{array}{l}\text { Above } 5 \text { years Experi. } \\
\text { B.Ed. Students-Teachers }\end{array}$ & 5 & 139.2 & 23.46 & & & & & \\
\hline $\begin{array}{l}\text { Arts Stream B.Ed. Student- } \\
\text { Teachers }\end{array}$ & 170 & 135.88 & 15.16 & \multirow{2}{*}{2.95} & \multirow{2}{*}{2.06} & \multirow{2}{*}{248} & \multirow{2}{*}{1.44} & \multirow[t]{2}{*}{$\begin{array}{l}\text { Not Significant at } \\
0.01 \& 0.05 \text { level }\end{array}$} \\
\hline $\begin{array}{l}\text { Science Stream B.Ed. } \\
\text { Student-Teachers }\end{array}$ & 80 & 138.83 & 15.17 & & & & & \\
\hline
\end{tabular}

\section{Testing of $\mathbf{H}_{02}$}

From the Table- 3, it is found that ' $t$ ' is significant if it is 1.97 or more. Since 2.01 is more than 1.97 (2.01 > 1.97), the difference between the two groups is significant at 0.05 level. Hence, the $\mathrm{H}_{02}$ is rejected and the researcher's $\mathrm{H}_{2}$ is accepted; that is to say that, there is significant difference between Male and Female B.Ed. Student-Teachers in respect of their attitude towards Practicum. It is due to the fact that the Male student-teachers have realized more importance of Practicum for their future professional life.

\section{Testing of $\mathbf{H}_{03}$}

From the Table- 3 , it is found that ' $t$ ' is significant if it is 1.97 or more at 0.05 level and 2.59 at 0.01 level. Since the calculated t value 3.96 is more than 1.97 and 2.59 (3.96 > $1.97 \& 2.59)$, the difference between the two groups 
is significant at 0.01 and 0.05 level. Hence, the $\mathrm{H}_{03}$ is rejected and the researcher's $\mathrm{H}_{3}$ is accepted; that is to say that, there is significant difference between Rural and Urban B.Ed. College Student-Teachers in respect of their attitude towards Practicum.

\section{Testing of $\mathbf{H}_{04}$}

From the Table- 3, it is found that ' $\mathrm{t}$ ' is significant if it is 1.97 or more at 0.05 level and 2.59 or more at 0.01 level. Since 0.36 is less than $1.97(0.36<1.97 \& 2.59)$, the difference between the two groups is not significant at 0.01 and 0.05 level. Hence, the $\mathrm{H}_{04}$ is accepted and the researcher's $\mathrm{H}_{4}$ is rejected; that is to say that, there is no significant difference between Pre-service and In-service B.Ed. Student-Teachers in respect of their attitude towards Practicum. It may seems to be that, an experienced on that field they can execute the programme easily. They already realize the importance of practicum in their professional fields.

\section{Testing of $\mathbf{H}_{05}$}

From the Table- 3, it is found that ' $\mathrm{t}$ ' is significant if it is 1.97 or more at 0.05 level and 2.59 or more at 0.01 level for $\mathrm{df}=248$. Since 4.01 is more than 1.97 ( $4.01>1.97 \& 2.59)$, the difference between the two groups is significant at 0.01 and 0.05 level. Hence, the $\mathrm{H}_{05}$ is rejected and the researcher's $\mathrm{H}_{5}$ is accepted; that is to say that, there is significant difference between Govt. Sponsored B.Ed. College and Private B.Ed. College StudentTeachers in respect of their attitude towards Practicum. It is due to the fact that, private colleges provide enough scope to be familiar with practicum.

\section{Testing of $\mathbf{H}_{06}$}

From the Table- 3 , it is found that' $\mathrm{t}$ ' is significant if it is 1.97 or more at 0.05 level and 2.59 or more at 0.01 level. Since 0.80 is less than $1.97(0.80<1.97 \& 2.59)$, the difference between the two groups is not significant at 0.01 and 0.05 level. Hence, the $\mathrm{H}_{06}$ is accepted and the researcher's $\mathrm{H}_{6}$ is rejected; that is to say that, there is no significant difference between $2^{\text {nd }}$ and $4^{\text {th }}$ Semester B.Ed. Student-Teachers in respect of their attitude towards Practicum.

\section{Testing of $\mathbf{H}_{07}$}

From the Table- 3, it is found that ' $t$ ' is significant if it is 1.97 or more at 0.05 level and 2.59 or more at 0.01 level. Since 0.16 is less than $1.97(0.16<1.97 \& 2.59)$, the difference between the two groups is not significant at 0.01 and 0.05 level. Hence, the $\mathrm{H}_{07}$ is accepted and the researcher's $\mathrm{H}_{7}$ is rejected; that is to say that, there is no significant difference between less than 5years and above 5 years B.Ed. Student-Teachers in respect of their attitude towards Practicum.

\section{Testing of $\mathrm{H}_{08}$}

From the Table- 3, it is found that ' $t$ ' is significant if it is 1.97 or more at 0.05 level and 2.59 or more at 0.01 level. Since 1.44 is less than 1.97 ( $1.44<1.97 \& 2.59$ ), the difference between the two groups is not significant at 0.01 and 0.05 level. Hence, the $\mathrm{H}_{08}$ is accepted and the researcher's $\mathrm{H}_{8}$ is rejected; that is to say that, there is no significant difference between Arts and Science stream Student-Teachers in respect of their attitude towards Practicum.

Table4. The N, Mean, SD of teaching experience less than 5 years, above 5 years and Fresher B.Ed. StudentTeachers

\begin{tabular}{|c|c|c|c|}
\hline Teaching Experience & N & Mean & SD \\
\hline Less than 5 years & 12 & 137.66 & 14.34 \\
\hline Above 5 years & 5 & 139.2 & 20.98 \\
\hline Fresher & 233 & 136.72 & 15.04 \\
\hline
\end{tabular}


Attitude of B.Ed. Student-Teachers towards Practicum

Table5. Results of ANOVA for Teaching Experience

\begin{tabular}{|c|c|c|c|c|c|c|}
\hline Sources of Variance & df & $\begin{array}{c}\text { Sum of } \\
\text { Squares }\end{array}$ & $\begin{array}{c}\text { Mean Square } \\
\text { Variance }\end{array}$ & F & \multicolumn{2}{|c|}{ Level of Significance } \\
\cline { 1 - 3 } Between groups & 2 & 39.013 & 19.506 & \multirow{2}{*}{0.84} & $0.05 \& 0.01$ & Not Significant \\
\cline { 1 - 3 } Within groups & 247 & 57425.887 & & & \\
\hline
\end{tabular}

Testing of $\mathbf{H}_{09}$

From the Table- 5 , it is found that, the computed F-value (0.84) is less than the critical value of F (4.68 \& 3.03 ) for 2 and $247 \mathrm{df}$ at 0.01 and 0.05 level of significance. Hence the null hypothesis $\mathrm{Ho}_{9}$ is accepted and $\mathrm{H}_{9}$ is rejected. It indicates that there is no significant difference among the attitude of B.Ed. Student-Teachers having teaching experience less than 5 years, above 5 years and fresher towards Practicum. Therefore it is concluded that teaching experience has no significant influence on the attitude of B.Ed. Student- Teachers towards Practicum.

Table6. The N, Mean, SD of Caste General, ST, SC, OBC B.Ed. Student-Teachers

\begin{tabular}{|c|c|c|c|}
\hline Caste & N & Mean & SD \\
\hline General & 108 & 135.2 & 14.80 \\
\hline SC & 34 & 139 & 15.63 \\
\hline ST & 19 & 135.1 & 16.75 \\
\hline OBC & 89 & 138.31 & 14.78 \\
\hline
\end{tabular}

Table7. Results of ANOVA for Caste

\begin{tabular}{|c|c|c|c|c|c|c|}
\hline Sources of Variance & df & $\begin{array}{c}\text { Sum of } \\
\text { Squares }\end{array}$ & $\begin{array}{c}\text { Mean Square } \\
\text { Variance }\end{array}$ & \multicolumn{2}{|c|}{ F } & \multicolumn{2}{|c|}{ Level of Significance } \\
\hline Between groups & 3 & 698.401 & 232.800 & & & \multirow{2}{*}{ Not Significant } \\
\cline { 1 - 3 } Within groups & 246 & 56766.499 & & 230.758 & $0.05 \& 0.01$ & \\
\hline Total & $\mathbf{2 4 9}$ & $\mathbf{5 7 4 6 4 . 9 0 0}$ & 2309 & \\
\hline
\end{tabular}

Testing of $\mathbf{H}_{010}$

From the Table- 7, it is found that, the computed F-value (1.009) is less than the critical value of F (3.85 \& 2.64) for 3 and $246 \mathrm{df}$ at 0.01 and 0.05 level of significance. Hence the null hypothesis $\mathrm{Ho}_{10}$ is accepted and $\mathrm{H}_{10}$ is rejected. It indicates that there is no significant difference among the attitude of General, SC, ST, and OBC B.Ed. Student-Teachers towards practicum in Purulia district. Therefore it is concluded that Caste has no significant influence on the attitude of B.Ed. Student-Teachers towards practicum in Purulia district.

\section{LIMITATIONS OF THE STUDY}

1. The researcher could not include all the B. Ed. Student-Teachers in the study.

2. The researcher could not use other research tools like interview, observation etc.

3. The present study was conducted only at surface level. It was not extensive and 'in depth' study.

4. Only Govt. Sponsored and Private B.Ed. Colleges under SKB University in Purulia district included in the study. 


\section{EDUCATIONAL IMPLICATIONS}

1. It is a humble attempt in this direction to assess the level of attitude of B.Ed. College Student-Teachers towards Practicum.

2. This study is very much essential for acquiring of rights skill, offering knowledge and shaping the desirable attitude towards Practicum.

3. This study is very much helpful for educational planners.

4. Special efforts should be made in order to develop the attitude among the B.Ed. Student-Teachers Practicum.

5. The study is very much helpful for emphasize on Practicum in the B.Ed. Programme.

6. The effort should be given in order to develop the attitude of Female student-teachers towards Practicum.

7. The effort should be given in order to develop the attitude of Urban B.Ed. student-teachers towards Practicum.

8. The effort should be given in order to develop the attitude of Fresher / Pre-service B.Ed. Student-Teachers.

9. The effort should be given in order to develop the attitude of Govt. Sponsored B.Ed. college student-teachers towards Practicum.

10. The effort should be given in order to develop the attitude of $2^{\text {nd }}$ semester student-teachers towards Practicum.

11. The effort should be given in order to develop the attitude of teaching experience less than 5 years B.Ed. student-teachers towards Practicum.

12. The effort should be given in order to develop the attitude of Arts student-teachers towards Practicum.

13. Special effort should be given in order to develop the attitude of General and OBC student-teachers towards Practicum.

14. The effort should be given in order to develop the attitude of Govt. Sponsored B.Ed. college student-teachers towards Practicum.

15. The effort should be given in order to develop the attitude of $2^{\text {nd }}$ semester student-teachers towards Practicum.

16. The effort should be given in order to develop the attitude of teaching experience less than 5 years B.Ed. student-teachers towards Practicum.

17. The effort should be given in order to develop the attitude of Arts student-teachers towards Practicum.

18. Special effort should be given in order to develop the attitude of General and OBC student-teachers towards Practicum.

\section{CONCLUSION}

From the light of the above discussion, we can say that the attitude of B.Ed. Student-Teachers in Purulia District of West Bengal is neither more favorable nor unfavorable towards Practicum i.e., satisfactory or average in attitude. Apart from that there are many other differences in their outlook towards practicum which are not at all desirable for an overall success or progress. As we all know that the Practicum is very much essential for the development of professional skills as well as teaching skills among the student-teachers. As a result of it a vital emphasis should be given on the ultimate improvement of practicum so that all the differences must be wiped out and more and more students would advance towards it and accept it willingly and happily. So, new and interesting topic should be added to the practicum in order to grow interest among the student-teachers. 


\section{REFERENCES}

Arroyo, A.R. (2011) Practicum Performance in Singapore and the Philippines of Hospitality Students in a State University", Asian Journal of Business Governance Business Education Section, 7(1), January, pp. 145-166

Beatrice, M.N (2014) Cognition of the role of cooperating teachers during the practicum in Kenya: Teachers of English perspective, Educational Research, Vol. 5(2) pp. 52-57, February,

Belete, A. (2013) The Attitude of School Teachers' /Mentors/ Towards Practicum Course in Debremarkos Town Primary School. International Journal of Technology Enhancements and Emerging Engineering Research, Vol 2, Issue 1.

Dweikat, K.A (2013) Attitudes of TEFL Student Teachers at QOU towards the Implementation of Practicum. Al-Quds Open University Journal for Educational \& Psychological Research \& Studies - Vol. 1 - No. 3 - October.

Ferrier-Kerr, J. L. (2009) Working together: Collaborative strategies for developing effective professional relationships in the practicum. Retrieved from http://www.aare.edu.au/

Haigh, M., \& Tuck, B. (1999) Assessing Student Teacher Performance in Practicum. New Zealand: Auckland College of Education.

Jusoh, Z. (2011) Teaching practicum: Student teachers' perspectives.

Mohan, R. \& Ghosh, A. K. (2011). Teacher Education, New Delhi: PHI Learning Private Limited.

Starkey, L. \& Rawlins, P. (2012) 'Student teacher learning during practicum experience', Tean Journal 4 (1) January [Online]. Available at: http://bit.ly/I5VJ5s (Accessed 05 January 2012).

Tuli, Fekede. (2009). Understanding Undergraduate Students Practicum Experience: A Qualitative Case Study of Jimma University. Ethiopian Journal of Education \& Science, 5(1), 107-116.

Wallace, Michael J.(1991) Training Foreign Language Teaching. Great Britain: Cambridge University Press. www.ncte-india.org/ncte_new/regulation2014/english/appendix4.pdf

Citation: Ankur Mahato, Dr. Santosh Kumar Behera. "Attitude of B.Ed. Student-Teachers towards Practicum" American Research Journal of Humanities and Social Sciences, vol 4, no. 1, 2018, pp. 1-13.

Copyright (c) 2018 Ankur Mahato, Dr. Santosh Kumar Behera. This is an open access article distributed under the Creative Commons Attribution License, which permits unrestricted use, distribution, and reproduction in any medium, provided the original work is properly cited. 